\title{
03
}

\section{ENABLING THE CITY: LEARNING FOR TRANSFOMATIONAL CHANGE}

\author{
Josefine Fokdal, Olivia Bina and Giulio Verdini
}

\section{Connecting to Global Agendas}

"All cities aim to increase prosperity, promote social inclusion, and enhance resilience and environmental sustainability” (SDSN, 2016, p. 21).

This chapter brings together some of the lessons drawn from previous chapters - the case studies, practice stories and the framework for inter- and transdisciplinary processes with three global agendas and their aspirations. Firstly, the New Urban Agenda (NUA); secondly the UN 2030 Agenda and the Sustainable Development Goals (SDGs), specifically goal no. 11 on Sustainable Cities and Communities and no. 4 on obtaining a quality education; and thirdly the Education for Sustainable Development (ESD) initiative led by the United Nations Educational, Scientific and Cultural Organization (UNESCO).

A key requirement of these global agendas is the need to be adaptable and local, which depends on the enhancement of capacities for "participatory, integrated and sustainable" planning and management. ${ }^{1}$ Implementing international, national and even regional policies and plans into the specific realities of cities and towns locally, is often problematic. Turning globally conceived agendas local means enabling interconnected and sustainable urban knowledge, and giving voice and legitimacy to a multiplicity of agencies, worldviews, ways of knowing and understanding the problems and the possibility for alternative ways of doing things.

We question how to localise the global agenda, in relation to the specific targets of the SDG on Sustainable Cities and Communities to "enhance inclusive and sustainable urbanization and capacity for participatory, integrated and sustainable human settlement planning and management in all countries" and explore the contribution of inter- and transdisciplinary processes to this. We then 
discuss some of the challenges faced by research and practice when attempting to contribute to systemic change in urban policy and management.

Our final section highlights the crucial potential role of higher education in generating more sustainable cities by connecting two aspects of the framework introduced in this book: the crosscutting dimension and quality of "learning," and the enabling condition of "competences and dispositions" in urban pedagogy in higher education ${ }^{2}$ with the international agenda. We focus on the collaborative practices arising from the actual engagement with such processes, which provide opportunities for mutual and transformational learning; and the recognised need for a wider application of inter- and transdisciplinary processes in the production of urban-related knowledge that entails changes in higher education - particularly in terms of competences and dispositions.

In doing so, we seek to strike a balance between support for the agendas and their optimistic embrace of inter- and transdisciplinary processes, for the transformational potential that certain interpretations of global urban and educational agendas may offer, and a cautious note regarding the persistent challenges to the ethos as well as the practice of inter- and transdisciplinarity and cooperation.

\section{From Global to Local - Persistent Challenges}

The New Urban Agenda was adopted in 2016 in Quito by the United Nations General Assembly. As the first document of its kind, it sets up a global standard for a more sustainable future and should be seen as a complementary document to the 2030 Agenda for Sustainable Development, signed by all 193 United Nations member states in 2015. Despite the high-level commitment of this document, and references to the importance of cities reaching the goals set out, it leaves many loopholes that are in many ways a reflection of limited progress in the overall sustainable development agenda (Göpel, 2016; WBGU, 2017).

The New Urban Agenda has, for example, been criticised for not being binding (Garschagen \& Porter, 2017) and in lacking actual guidance on how to reach the targets. (e.g. Satterthwaite, 2017). It is also criticised for taking a techno-managerial approach that lacks innovation (Kaika, 2017), amongst other things. Moreover, the New Urban Agenda and Sustainable Development Goals have universal ambition, unlike the previous Millennium Development Goals that primarily focused on the least developed countries. This means that most of the normative assumptions and general statements incorporated may be relevant in one context and less so in others (Parnell, 2015). This is the case of the "right to the city" discourse, an agenda pushed by civil society organisations of Latin American countries and not necessarily fully shared by others (Watson, 2016). The "right to the city" discourse has gained ground in scholarly debates, over the last few decades (Brenner et al., 2012; Mayer, 2012; Harvey, 2012) and, as a result of the late 1960s' protests, has demanded a stronger focus on social use values rather than on capital exchange value (Lefebvre, 1968; Schmid, 2012). It is an approach based on the need to change the way cities are governed in order to make them more inclusive (Cirolia et al., 2015). First coined by Lefebvre, the "right to the city" is a vision for an urban future, in which power relations are rebalanced and civil society - and modes of collaboration - play a much stronger role in shaping the urban, reducing inequalities. The Sustainable Development Goals, and consequently the New Urban Agenda, take into consideration how to tackle poverty, ${ }^{3}$ however, they also seem to deliberately ignore some of the underlying conditions of urban injustice, notably those related to the impact of financialisation of urban development processes and housing markets (Farha \& Porter, 2017). Based on this, advocacy for the "right to the city" seems rather loose 
and meaningless, and the New Urban Agenda, therefore, appears still to be based on an underlying neoliberal framework of urban competitiveness, modernisation and economic growth (Huchzemeyer, 2018).

In terms of urban planning, it is not a coincidence that, in the aftermath of the launch of the New Urban Agenda, some eminent dissonant voices emerged. Richard Sennett, Ricky Burdett and Saskia Sassen, together with the former executive director of UN-HABITAT Joan Clos, pointed to the still persisting ideology of modernity and order in the way to produce contemporary cities and design mainstream urban policies. As explained in the so-called Quito Papers, such ideology produces a dystopia of segregation of functions, pursued for the sake of efficiency, particularly in emerging countries (Sennett et al., 2018). The pervasiveness of the concept of urban tabula rasa in modern planning, which has justified, for example, large-scale demolitions of existing neighbourhoods over recent decades, has generated a plethora of examples of arbitrary practices of urban clearing, particularly of the so-called slums. This has been instrumental in developing highly profit-driven real estate developments, often isolated and gated from the rest of the urban life. Therefore, in response to the growing problems and tensions arising from rapid urbanisation, the Quito Papers call for a new, non-violent urban ethic, which refuses the over-specification of functions and forms imposed by pure market-led urban processes (Sennett et al., 2018). Their criticism of contemporary urbanism stems from an awareness of the need to change the current practice, and the mindset, of those in charge of planning contemporary cities, by re-learning the art of designing cities and opposing the status quo of urban speculation.

Their contribution is just the latest in a long history of critique. The claim of the failure of modern and rational planning has mobilised some of the most important intellectuals of the twentieth century such as Jane Jacobs (Jacobs, 1961). However, despite rich academic debates and activists' works, this has not necessarily implied a new season of innovative urban practices. On the contrary, bureaucratic and top-down approaches have been only replaced by the free market and capitalism, leading to different forms of rigid, closed, profit-driven and ultimately unsustainable processes of urban transformation. Sennett et al. (2018), therefore, ultimately advocate for open-system thinking in designing the cities of tomorrow, beyond narrow market demands. In doing so, they respond to the long-lasting, yet not completed, critical revision of modernist urban planning principles. In recent decades, it is undoubtedly evident that efforts have been made to identify causes and possible remedies of fast urbanisation processes and to move towards a new paradigm of urban sustainability (UN-HABITAT, 2009). Admittedly, the Quito Papers (2018) did not consider this enough. They instead suggest the development of "a new science of urbanization" that would require a systemic approach to integrate "competences in municipal finance, urban planning and design and urban regulation" to produce a more inclusive and sustainable urbanisation.

The persistent challenges outlined here with reference to urban policies and new ways of undertaking science and producing knowledge are in many ways an echo of challenges to the transformative changes needed to shift towards sustainable patterns of development (Brand, 2014; Sachs et al., 2019; WBGU, 2017). We now turn to explore bridges between agendas, and learn from their common difficulties, from seedlings of locally based successes, and from the promise arising out of transformative learning. 
Target 11.1

By 2030, ensure access for all to adequate, safe and affordable housing and basic services and upgrade slums.

Target 11.2

By 2030, provide access to safe, affordable, accessible and sustainable transport systems for all, improving road safety, notably by expanding public transport, with special attention to the needs of those in vulnerable situations, women, children, persons with disabilities and older persons.

(1)

Target 11.3

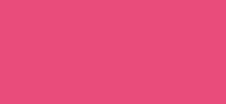

By 2030, enhance inclusive and sustainable urbanization and capacity for participatory, integrated and sustainable human settlement planning and management in all countries.

Target 11.4

Strengthen efforts to protect and safeguard the world's cultural and natural heritage.

Target 11.5

By 2030, significantly reduce the number of deaths and the number of people affected and substantially decrease the direct economic losses relative to global gross domestic product caused by disasters, including water-related disasters, with a focus on protecting the poor and people in vulnerable situations.

(1)

Target 11.6

By 2030, reduce the adverse per capita environmental impact of cities, including by paying special attention to air quality and municipal and other waste management.

Target 11.7

By 2030, provide universal access to safe, inclusive and accessible, green and public spaces, in particular for women and children, older persons and persons with disabilities.

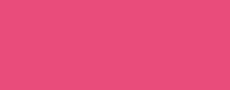

Target 11.A

Support positive economic, social and environmental links between urban, peri-urban and rural areas by strengthening national and regional development planning.

\section{Target 11.B}

By 2020, substantially increase the number of cities and human settlements adopting and implementing integrated policies and plans towards inclusion, resource efficiency, mitigation and adaptation to climate change, resilience to disasters, and develop and implement, in line with the Sendai Framework for Disaster Risk Reduction 2015-2030, holistic disaster risk management at all levels.

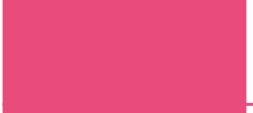

Target 11.C

Support least developed countries, including through financial and technical assistance, in building sustainable and resilient buildings utilizing local materials.

FIGURE IV.3.2 Targets for Sustainable Development Goal no. 11 and the Relevance of Inter- and Transdisciplinary Processes. Source: UNGA (2015); https://sustainabledevelopment.un.org/ 


\section{The Sustainable Development Goal for Cities and Communities (no. 11) and Inter- and Transdisciplinary Processes}

"For a truly participatory process, public engagement and collaboration should be enabled through the whole cycle of SDG planning, implementation and evaluation” (SDSN, 2016, p. 21).

Inter- and transdisciplinary approaches to the design and implementation of urban research and practice can be considered essential tools for implementing the United Nations sustainability agenda, as discussed in our Introduction (Chapter I.1) and in Chapter I.2. Here, barriers such as institutional structures, limited time availability, lack of competences and dispositions for guiding inter- and transdisciplinary processes have been identified. Interdisciplinary approaches can help to set agendas for policymaking and planning that break down some of these barriers, and transdisciplinarity can ensure that a plurality of actors - both directly and indirectly affected - is engaged in such processes. There have been plenty of calls for new approaches to knowledge production (e.g. Regeer and Bunders, 2009; Hirsch Hardorn et al., 2008), and promoting the transformative changes implied by Sustainable Development Goals will require a significant breaking down of traditional silos in urban governance and related institutions.

While our case studies were not designed to contribute directly to Sustainable Development Goals, Table IV.3.1 opposite shows how all of them address one or more aspect of Sustainable Development Goal no. 11: "Make cities and human settlements inclusive, safe, resilient and sustainable," which includes targets (Figure IV.3.2) related to housing, transport, planning, heritage, vulnerability, environment, public space, urban-rural policies, capacity development and large-scale environmental changes. ${ }^{4}$ Inter- and transdisciplinary processes of knowledge production are meant to enhance our capacity for collaboration, both in terms of ethos and practice, and are thus a critical means for reaching Target 11.3, which aims "by 2030, [to] enhance inclusive and sustainable urbanization and capacity for participatory, integrated and sustainable human settlement planning and management in all countries." The case studies and practice stories in Parts II and III discuss knowledge processes that respond in part to the requirements identified in this target.

\section{Time and (Limited) Systemic Change}

The assumption behind the new drive for transformative planning and policy, embedded in much of the literature and guidance for implementation of Sustainable Development Goals, is that participatory processes, which include what we call in this volume transdisciplinarity - with co-design, coproduction, dissemination and continuation as crucial stages in our framework - are rebalancing power relations, enforcing a re-learning and the production of new knowledge and, thus, leading to more inclusive and sustainable solutions. The expectation, however, that "a truly participatory process, public engagement and collaboration should be enabled through the whole cycle of SDG planning, implementation and evaluation" (SDSN, 2016, p. 21) clashes with the multiple obstacles of far lesser expectations in this arena. In Chapter I.2, we discuss the desirability and significant challenges of a "continuation phase." That time matters is generally recognised in the inter- and transdisciplinary discourse. From Parts II and III, time especially matters in terms of building trust on different levels (individual, institutional and within a team) and in terms of experiences (so time of engagement). In a study on the kind of system change needed for a more sustainable future, Jordan et al. (2013, p. 60) identified four categories of what they call "societal entrepreneurship": event-focused, operations-centric, systemic and dialectical. Event-focused societal entrepreneurship 


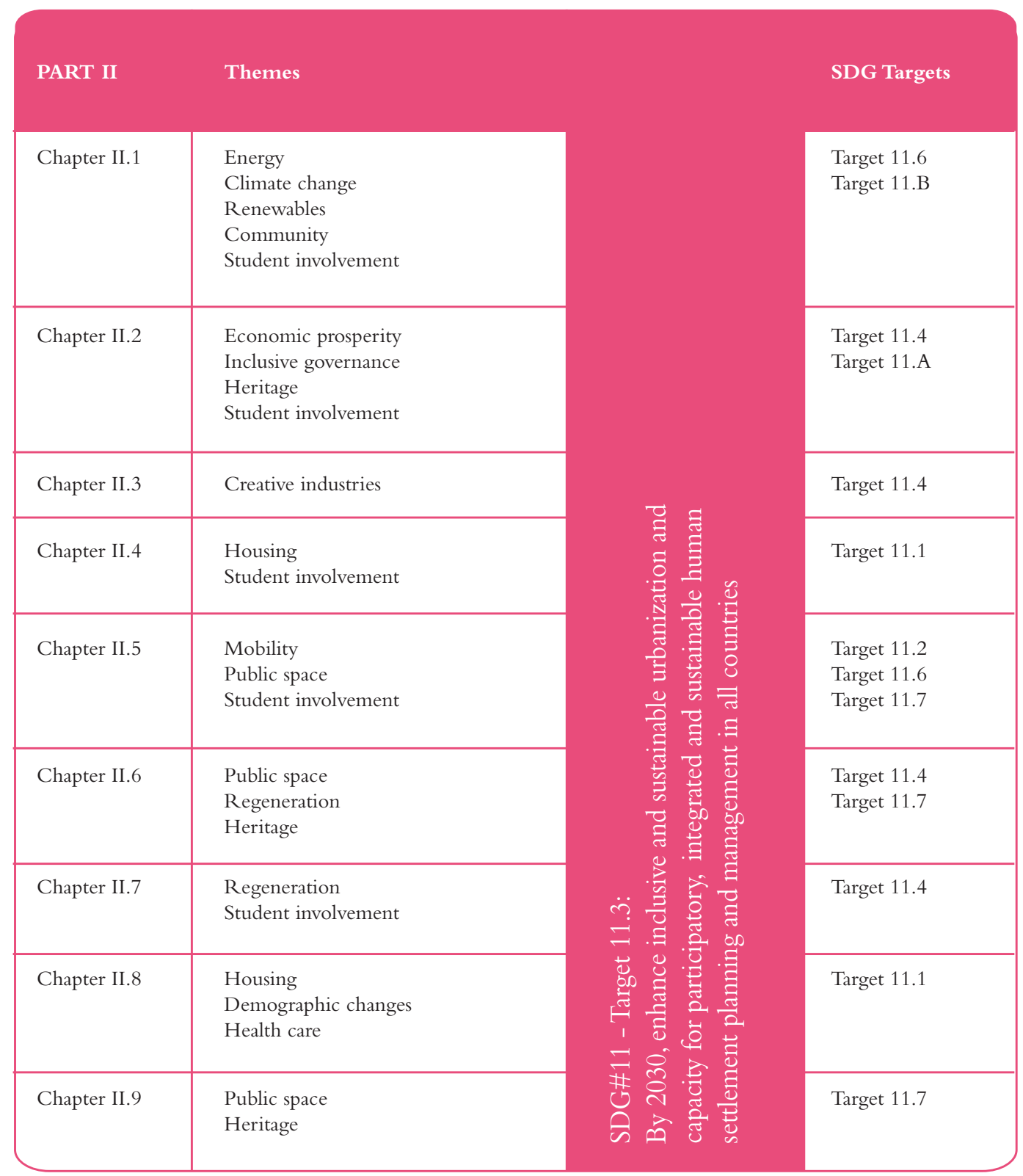

TABLE IV.3.1 Part II Urban Stories and Sustainable Development Goal Themes and Priorities. Source:Authors. 
focuses on single events and does not necessarily aim at systemic change beyond creating awareness around a topic through the event. Operations-centric societal entrepreneurship involves a group of people that are interested in solving a specific societal problem that they have identified. Systemic societal entrepreneurship aims at influencing how other actors or systems behave by advocacy and showing how things can be done differently. Finally, dialectical societal entrepreneurship includes a strong perspective awareness, which is not the case in the three other types, and requires time.

The dissatisfaction with the lack of time and limited change on the systemic level as described in several cases (e.g. Dimitrova, Verdini et al., Nikšič, Paadam and Ojamäe, all this volume) is at the basis of the discrepancy between the actual engagement as a more operations-centric societal entrepreneurship and the envisioned impact on a systemic level. What the cases in Parts II and III describe, however, is also that most of the inter- and transdisciplinary processes in the local urban setting are navigating within the realm of event-focused or operations-centric societal entrepreneurship. In particular, in the cases in which students are involved (Chiles et al., Nikšič, Verdini et al., Dietz et al., Dimitrova, Gromark et al., all this volume), the time constraints of semesters and academic schedules are described as an obvious obstacle to real transformation. As long as inter- and transdisciplinary processes stay within these two realms, however, a systemic change will not happen, reflecting wider reviews of challenges and obstacles to the kind of transformative change expected in relation to sustainability. There is a need to move beyond these two approaches and to move towards a more systemic and dialectical societal entrepreneurship, especially if we are to localise international agendas such as the New Urban Agenda and the Sustainable Development Goals.

\section{Learning and Re-learning for Transformational Change}

Re-learning how to design cities and testing new approaches to urbanism entails a new mindset for planners, architects and all those involved in shaping and inhabiting the processes of urbanisation.

This requires two major changes in the realm of knowledge to envision a new paradigm for twenty-first-century urbanism, which are well rehearsed (see Chapter I.2 and Chapter IV.1 in this volume) but far from orthodoxy. The first implies the capacity to deliver new forms of knowledge in new ways, questioning the roles of traditional actors involved in the process of shaping cities. This is witnessed in the inter- and transdisciplinary processes analysed in this volume. The second requires new educational models to shape the priorities of sustainable development, as in the Rio Declaration (UNCED, 1992) and the resulting United Nations Educational, Scientific and Cultural Organization initiative on Education for Sustainable Development (2009). Agenda 2030 reinforces this in its Sustainable Development Goal no. 4 to "ensure inclusive and equitable quality education and promote lifelong learning opportunities for all." Crucially, underlying the United Nations agenda is the assumption that education plays an essential role in achieving all Sustainable Development Goals, therefore requiring systemic, connected and collaborative thinking (Leicht et al., 2018; SDSN Australia/Pacific, 2017; UNESCO, 2017).

All this has implications for educational practices for sustainable urban development, where progress has been made, and yet significant changes remain pending (Bina et al., 2016). The opensystem thinking, which Sennett et al. (2018) relate to as a re-learning of how to design cities, finds interesting correlations with core characteristics of the Education for Sustainable Development as propagated by the United Nations Educational, Scientific and Cultural Organization: 
"it requires individuals to act in complex situations in a sustainable manner - to explore new ideas and approaches and participate in socio-political processes, with the objective of moving their societies progressively towards sustainable development. ESD, understood in this way aims to enable learners to take responsible actions that contribute towards creating sustainable societies now and in the future" (Rieckmann, 2018, p. 39).

Education for Sustainable Development entails the development of cross-cutting competences and learning outcomes (cognitive, socio-emotional and behavioural) crucial to achieve the Sustainable Development Goals. In practice, education needs to be forward-looking and propose approaches and models that can: deal with complex sustainability challenges; enable individuals to reflect on their actions, taking into account their current and future impacts (from a local and global perspective); enable individuals to act in complex situations in an innovative and sustainable manner, participating in socio-political processes; promote sustainable development and lifestyles. This is achieved not only by integrating topics directly or indirectly linked to the domain of "sustainability" into teaching curriculums (such as climate change, inequality, and so on), but also by facilitating innovative, interactive, learner-centred educational settings:

"ESD ... takes the form of an action-oriented transformative pedagogy, characterized by elements such as self-directed learning, participation and collaboration, problem-orientation, and inter and transdisciplinarity, as well as the linking of formal and informal learning. Such pedagogical approaches are essential for the development of competencies vital for promoting sustainable development” (Rieckmann, 2018, p. 40).

Through our exploration of inter- and transdisciplinary processes in practice, we note a significant overlap between the needs of education for sustainability, of a new planning paradigm, and those of inter- and transdisciplinary science: 1) greater collaboration and learning between different actors and parties directly and indirectly involved in urban projects, and 2) greater integration and connectedness between ways of knowing and disciplinary perspectives and insights.

\section{Forms of Learning Through Inter- and Transdisciplinary Processes}

As the diverse experiences in this volume show, it is not so much methods that "enable the city," but rather competences and dispositions combined with mutual and transformational forms of learning. Building on the work of Julie Klein (2013), Mitchell et al. (2015) define mutual learning as a social aspect that is context dependent and focuses on the interaction between collaborating partners, and their collaborative generation of new insights:

"The social aspect of learning ... draws attention to the interactions, communications and relations amongst actors and the quality of dialogue leading to collective definitions and accommodations in terms of both the nature of the situation to be addressed and the means of determining desirable and feasible pathways. It is the experience of the collaborative, coordinated research endeavour that provides the enabling environment for the depth of reflection associated with deeper conceptual change. This kind of learning can occur at group, community, or societal scales" (2015, p. 93).

Mitchell et al.'s (2015) description of transformational learning is illuminating in terms of the value of inter- and transdisciplinary processes for their potential to trigger both mutual learning and a deep, 


\begin{tabular}{|c|c|c|c|}
\hline PART II & Forms of learning & $\begin{array}{l}\text { Topic/context } \\
\text { around which } \\
\text { perceptions } \\
\text { were changed }\end{array}$ & Change \\
\hline Chapter II.1 & $\begin{array}{l}\text { New social relations were built and the } \\
\text { weekly meetings facilitated mutual } \\
\text { learning. Learning has a double connota- } \\
\text { tion here: education through the } \\
\text { involvement of students and the mutual } \\
\text { learning within the community. }\end{array}$ & $\begin{array}{l}\text { Renewable } \\
\text { energy }\end{array}$ & $\begin{array}{l}\text { A dialogue was established and people were } \\
\text { brought together and established a common } \\
\text { language, recognising the history of the } \\
\text { place. }\end{array}$ \\
\hline Chapter II.2 & $\begin{array}{l}\text { The format was already established. } \\
\text { students acted as individual "change } \\
\text { agents" at the same time building } \\
\text { capacities and empowering through } \\
\text { shared learning experiences. }\end{array}$ & $\begin{array}{l}\text { Economic } \\
\text { prosperity }\end{array}$ & $\begin{array}{l}\text { "A positive atmosphere for change," already } \\
\text { partially established, helped to develop new } \\
\text { ideas and linking different initiatives. }\end{array}$ \\
\hline Chapter II.3 & $\begin{array}{l}\text { The mutual learning in this case is } \\
\text { part of the process. }\end{array}$ & $\begin{array}{l}\text { Creative } \\
\text { industries/entre- } \\
\text { preneurship }\end{array}$ & $\begin{array}{l}\text { There was a changing perception of the risks } \\
\text { related to ITD and the role researchers can } \\
\text { play in accompanying a transformative } \\
\text { process. }\end{array}$ \\
\hline Chapter II.4 & $\begin{array}{l}\text { The experiment of developing new ways } \\
\text { of residing involved mutual learning for } \\
\text { all actors involved. In particular, the } \\
\text { monthly meeting over several years } \\
\text { facilitated the dialogue and the respect } \\
\text { and value of different kinds of knowled- } \\
\text { ge. Also, a PhD was written within the } \\
\text { process. }\end{array}$ & Housing & $\begin{array}{l}\text { The hierarchies of knowledge were } \\
\text { "broken" down due to long-term } \\
\text { involvement. }\end{array}$ \\
\hline Chapter II.5 & $\begin{array}{l}\text { The community learned with the } \\
\text { research team through the method of } \\
\text { experimenting! In this case a tempo- } \\
\text { rary installation was used as a starting } \\
\text { point. }\end{array}$ & $\begin{array}{l}\text { Mobility and } \\
\text { quality of public } \\
\text { space }\end{array}$ & $\begin{array}{l}\text { The belief that something can change - } \\
\text { empowerment - led to the establishment of } \\
\text { the association that continues to facilitate a } \\
\text { dialogue around the quality of the public } \\
\text { space. }\end{array}$ \\
\hline Chapter II.6 & $\begin{array}{l}\text { The multifaceted extensive research was a } \\
\text { new approach in the context of planning } \\
\text { culture. The "urban forums" facilitated a } \\
\text { participatory dialogue. }\end{array}$ & Regeneration & $\begin{array}{l}\text { The "urban forums" created a "safe space" to } \\
\text { discuss the development of the city. }\end{array}$ \\
\hline Chapter II.7 & $\begin{array}{l}\text { Twofold learning: 1) education of future } \\
\text { planners and the fact that collaboration } \\
\text { did not work in the way that was } \\
\text { intended led to "learning by failure." And } \\
\text { 2) a self-reflexive process within the } \\
\text { involved academic community. }\end{array}$ & Regeneration & $\begin{array}{l}\text { The processes catalysed a self-reflexive } \\
\text { process within the academic community and } \\
\text { was used as a starting point for a new } \\
\text { dialogue. }\end{array}$ \\
\hline Chapter II.8 & $\begin{array}{l}\text { Experience matters! People learn from } \\
\text { past experiences and transfer the lessons } \\
\text { learned (context-independent knowled- } \\
\text { ge) into new ITD processes. }\end{array}$ & $\begin{array}{l}\text { Health, dementia } \\
\text { and housing }\end{array}$ & $\begin{array}{l}\text { Good leadership is manifested as the } \\
\text { conductor of an orchestra - someone who is } \\
\text { capable of sensing when and what has to be } \\
\text { said or done by whom. }\end{array}$ \\
\hline Chapter II.9 & $\begin{array}{l}\text { The mutual learning was that a new way } \\
\text { of interaction was needed and trust } \\
\text { building around a local context that is } \\
\text { highly contested happened. }\end{array}$ & $\begin{array}{l}\text { Neighbourhood } \\
\text { development - } \\
\text { quality of public } \\
\text { space }\end{array}$ & $\begin{array}{l}\text { Clarification of the need to strengthen } \\
\text { cooperation between the state, local } \\
\text { authorities, residents and academic institu- } \\
\text { tions. }\end{array}$ \\
\hline
\end{tabular}

TABLE IV.3.2 Illustrates the forms of learning explored in the cases illustrated in Part II. Source:Authors. 
triple loop learning (Schön, 1983), which partly echoes with the interpretation of transdisciplinarity explored in Chapter IV.1 (this volume):

\begin{abstract}
"Transformative, higher order, 'conceptual', 'generative' learning involves changes in norms and values, redefining goals that govern the decision-making process, reviewing and adjusting problem definitions (or perceptions of real-world situations), strategies, and actions of organisations and individuals involved. Transformational learning as defined in this framework denotes learning that leaves a legacy and contributes to changing the situation. ... creating change towards sustainable futures requires persistent change in both cognitive and behavioural realms. Persistent change is associated with these higher order, deeper, levels of learning that enable new perspectives and open up new possible paths. Shifts of this kind require a supportive organisational culture - one that values experimentation and "learning from failure"” (Mitchell et al., 2015, p. 93).
\end{abstract}

The case studies and practice stories emphasise different competences and skills as well as methodologies, reflecting different contexts (institutional, cultural, political, etc.). The chapters by Paadam and Ojamäe (Chapter II.6), and Wolf et al. (Chapter II.4; all this volume), both reflect on deep lessons that can be learned from inter- and transdisciplinary urban research processes. The chapters by Gromark et al. (Chapter II.3), Chiles et al. (Chapter II.1) and Nikšič (Chapter II.9; all this volume) are grounded in the traditions of participatory urban planning and action research and focus on designing and implementing transdisciplinary processes around architecture and urban planning. Finally, the chapters by Verdini et al. (Chapter II.2), Dietz et al. (Chapter II.5), and Dimitrova (Chapter II.7; all this volume) centre around pedagogical models of including interand transdisciplinary learning processes in urban planning education and the role of academia as facilitator of inter- and transdisciplinary processes.

\title{
Education for Sustainable Development Competences and Dispositions in the Urban Realm
}

This view of transformational learning has significant implications for the Education for Sustainable Development agenda connected to Sustainable Development Goal no. 4. However, and more significantly, learning and education are considered instrumental to the success of the whole United Nations 2030 Agenda, which seeks to trigger transformational change in all the fields identified by Sustainable Development Goals. In this chapter, we have focused on Sustainable Development Goal no. 11 as an example of such connection; to promote the new science of urbanisation as discussed above, the next generation of urban planners, architects and urban administrators and leaders will need:

- “'Cross-cutting skills' and 'key competencies' that are relevant to addressing all of the SDGs: systems thinking, critical thinking, self-awareness, integrated problem-solving, and anticipatory, normative, strategic and collaboration competencies.

- Creativity, entrepreneurship, curiosity and learning skills, design thinking, social responsibility, partnership competencies, and being comfortable in inter-disciplinary settings.

- A basic understanding of the subject areas of each of the SDGs.

- Knowledge and understanding of the SDG framework itself and its purpose and uses"' (SDSN, 2017, p. 12). 


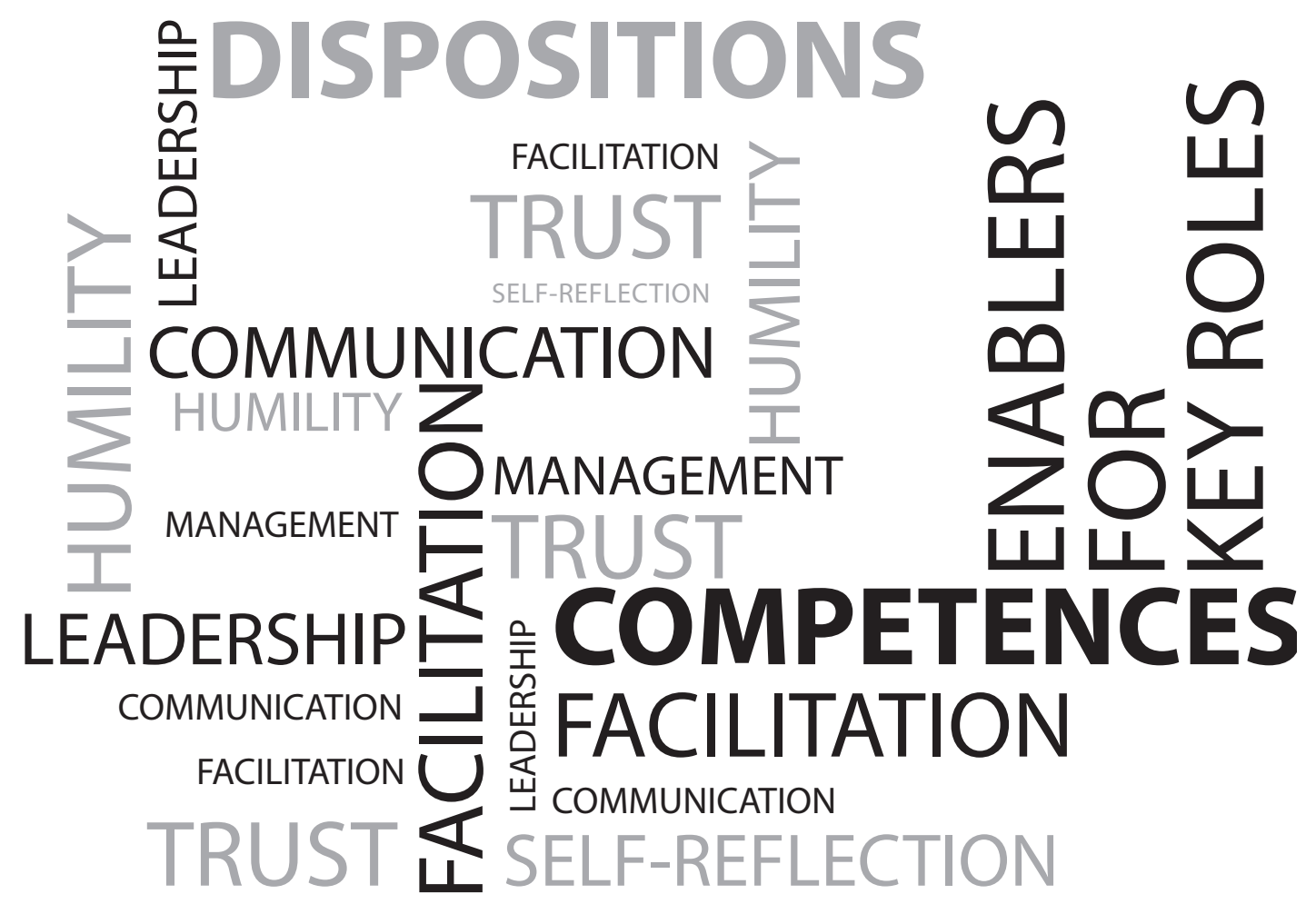

FIGURE IV.3.3 Illustrates the forms of learning explored in the case studies in Part II. Source:Authors.

We acknowledge that the two dimensions of competences and dispositions are not always easily distinguished; thus, for example, the definition of competences according to the United Nations Educational, Scientific and Cultural Organization embraces knowledge, capacities and skills, motives and affective dispositions:

"... the specific attributes individuals need for action and self-organization in various complex contexts and situations. They include cognitive, affective, volitional and motivational elements; hence they are an interplay of knowledge, capacities and skills, motives and affective dispositions. Competencies cannot be taught but need to be developed through learning." (2017, p. 10).

Nevertheless, as we explain in Chapter I.2 and in our working definitions in Chapter I.3, we consider that a separation of the two concepts helps to see their importance and thus build capacity for both. Table IV.3.2 and Figure IV.3.3 summarise the main competences and dispositions discussed by the INTREPID network and recommended as key to "Enabling the City." 


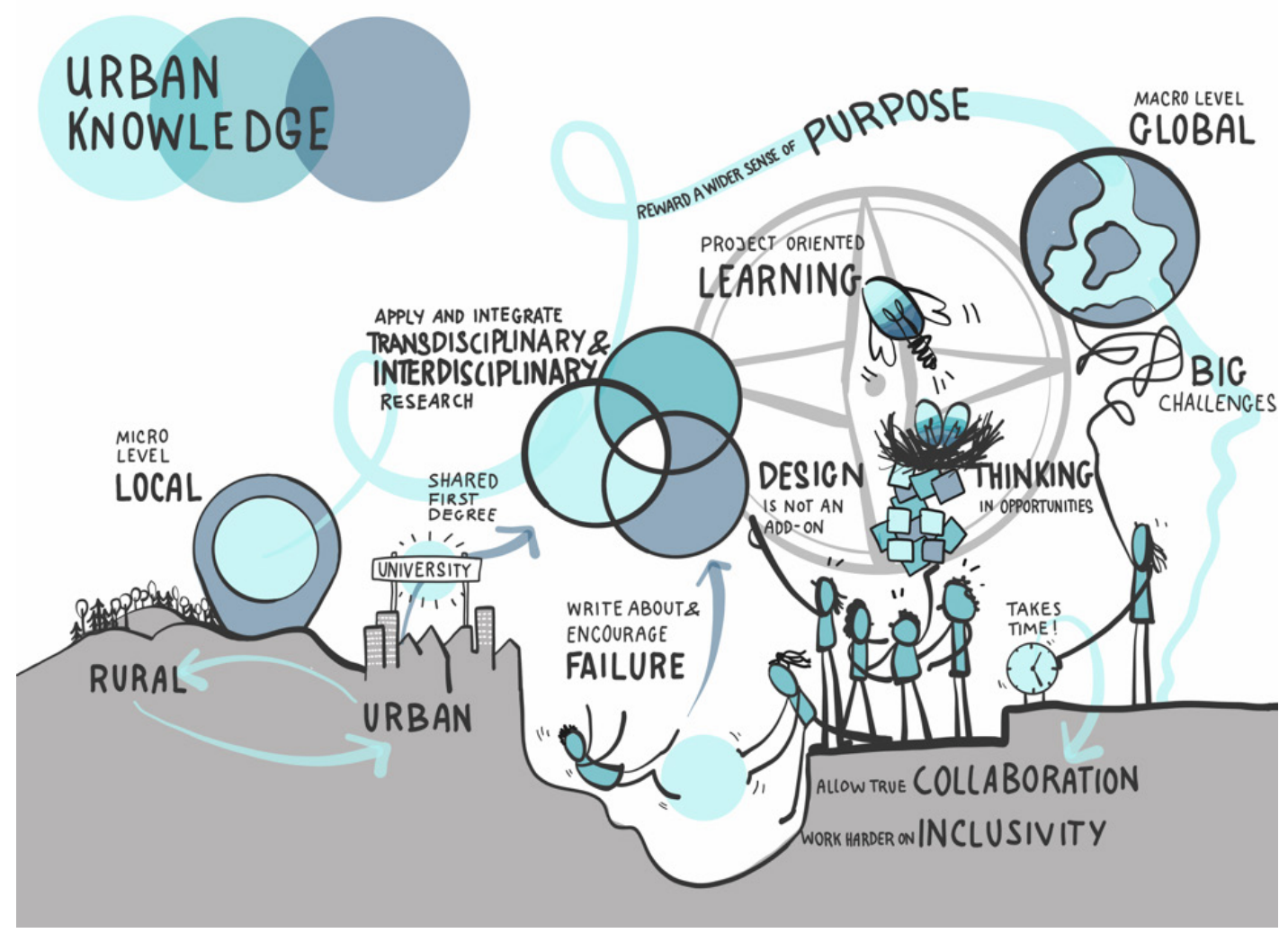

FIGURE IV.3.4 Urban knowledge and its challenges. Source: Jacob Kohlbrenner in Bina et al. (2019).

The experience from our cases and discussions over four years highlight the need for courage and a certain disposition towards risk-taking (explored in depth in Guimarães et al., 2019), as well as the capacity to embrace the inevitable ambiguity that arises from inter- and transdisciplinary processes.

The changing face of "leadership" and its constant overlap with the ubiquitous role of "facilitator" have been the subject of most of our cases. Some of the most common qualities expected in the spectrum of leader-facilitator include a combination of capabilities and dispositions: being committed, capable of promoting connectedness and building bridges, being a good communicator and listener - capable of exploring and clarifying differences and ambiguities, being flexible and adaptable, and capable of promoting learning. Another key role that occupies the spectrum between leadership and facilitator is that of "change agent and societal entrepreneur," who is motivated by societal transformation, and who can aid transformation towards more sustainable futures by being aware of complexities (key for system-wide changes).

Figure IV.3.4 summarises the main challenges involved in inter- and transdisciplinary processes that specifically address urban knowledge, as seen through the eyes of the INTREPID network 
UNESCO critical competences for sustainability
Quito Papers and illustrations from cases in Part II

To recognise the contested nature of the urban realm, interpreting different rationales of stakeholders (Chapter II.4; Chapter II.8).
Normative competency: the abilities to understand and reflect on the norms and values that underlie one's actions; and to negotiate sustainability values, principles, goals and targets in a context of conflicts of interests and trade-offs, uncertain knowledge and contradictions.
Critical thinking competency: the ability to question norms, practices and opinions; to reflect on own one's values, perceptions and actions; and to take a position in the sustainability discourse.
To acknowledge the limits of mainstream modernist practices, taking positions and opposing narrow visions of city development (i.e. those driven by real estate speculation). (Chapter II.9; Chapter II.6).
Systems thinking competency: the abilities to recognise and understand relationships; to analyse complex systems; to think how systems are embedded within different domains and different scales; and to deal with uncertainty.
To stimulate reflections on complex local system, provoking discussions on uncertainty. Examples: reflecting holistically on environmental constraints and social aspirations of communities (Chapter II.2; Chapter II.8).
Integrated problem-solving competency: the overarching ability to apply different problem-solving frameworks to complex sustainability problems and develop viable, inclusive and equitable solution options that promote sustainable development, integrating the above-mentioned competences.
To focus on concrete problems when discussing solutions with local stakeholders (all case studies in Part II).
Self-awareness competency: the ability to reflect on one's own role in the local community and (global) society; to continually evaluate and further motivate one's actions; and to deal with one's feelings and desires.
To develop in situ learning experiences where students/community interaction can take place (Chapter II.1; Chapter II.2; Chapter II.5 and Chapter II.7).
Collaboration competency: the abilities to learn from others; to understand and respect the needs, perspectives and actions of others (empathy); to understand, relate to and be sensitive to others (empathic leadership); to deal with conflicts in a group; and to facilitate collaborative and participatory problem-solving.
To work across different disciplinary fields, setting up multidisciplinary teams, and to facilitate collaborative practice with local citizens (Chapter II.1; Chapter II.4 and Chapter II.5).
Strategic competency: the abilities to collectively develop and implement innovative actions that further sustainability at the local level and further afield.
To initiate alternative strategies for sustainable urban planning, by incorporating different expertise from academia and practice (Chapter II.6).
Anticipatory competency: the abilities to understand and evaluate multiple futures - possible, probable and desirable; to create one's own visions for the future; to apply the precautionary principle; to assess the consequences of actions; and to deal with risks and changes.
To develop alternative visions for urban futures and to test local solutions of urban sustainability (Chapter II.1; Chapter II.2; Chapter II.3; and Chapter II.9).

TABLE IV.3.3 United Nations Educational, Scientific and Cultural Organization Critical competences for Sustainability: Global and Local Relevance.] Source: UNESCO 2017 with Author's commentary. 
scholars and practitioners. It overlaps with most of the United Nations Educational, Scientific and Cultural Organization (2017) competences for sustainability in Table IV.3.3. It refers to the constructive tension between local and global focus, central to the agendas of the Sustainable Development Goals and New Urban Agenda and linked to the United Nations Educational, Scientific and Cultural Organization's self-awareness competence, to the importance of acknowledging a sense of purpose and thus the United Nations Educational, Scientific and Cultural Organization's normative and critical thinking competences. It also calls for greater collaboration between the city and university (in line with ideas of civic universities).

Table IV.3.3 brings together the United Nations Educational, Scientific and Cultural Organization's (2017) set of eight competences for sustainability (which include what we call here dispositions) with our recommended categories and a reflection on how all this links to the global priorities identified by the influential set of Quito Papers, and to the local experience of our cases.

This book has explored how collaborative processes of knowledge production, and learning, may contribute to craft transformative pathways. The case studies (Part II) and the practice stories (Part III) are examples of collaborative processes, framed as experiments of inter- and transdisciplinary science that is almost ubiquitously expected to help produce more inclusive and sustainable results (see also Chapter I.2 of this volume). These experiments show a diversity of experiences and traditions of spatial planning within several European countries. While, in some countries, participatory processes are established practice and embedded in the legal planning framework (e.g. Germany), other countries have just started to experiment with other modes of collaboration. This is the case with the establishment of "Urban Forums," as in the city of Tallinn, or through the experimentation of bottom-up trust-building processes, as illustrated by the cases of Ljubljana and Gagliato, due to a long-lasting mistrust in the state. Taken together, this diversity of experiences reinforces the assumption that enhanced collaboration among all actors in cities, at different scales, is conducive of more sustainable urban outcomes and essential for re-learning and consequently for dealing with the urban complexity of the twenty-first century (Griffith et al., 2018). In the present volume, the cases provided show how inter- and transdisciplinary processes enable micro-scale forms of knowledge production, of mutual learning and collaborative science deemed essential for cities to develop more sustainably. Forms of re-learning of the art of producing urban space, not just physically but also socially and economically, are taking place at the very local scale (neighbourhood, village and so on). While essential to all levels of policy and planning, such experiences show a significant potential for triggering innovative learning at the local level.

\section{Concluding Remarks}

As twenty-first-century problems accelerate in scale, pace and interconnectedness, even the term "wicked problem" (Hulme, 2009) feels somewhat insufficient to grasp what is at stake. The rising popularity of the term "transformative" (including for the United Nations 2030 Agenda: UNGA, 2015) as opposed to more incremental "transitions" (Brand, 2014), seems to underpin this inconvenient state of affairs. Partly in response to this, we are witnessing a relentless growth in the demand for collaborative and participatory processes, co-designing and co-producing problems and solutions. The plethora of global, regional, national and local assessments and planning efforts appear to be embracing (or at least paying lip service to) such processes. Yet, for all the clamour, we are still largely having to find the way to such processes, case by case. While cases, lessons and frameworks (including ours) help, much in our cultures, institutions, worldviews and incapabilities still does not. 
Resistance and inability to promote transformative change have a long tradition, and in this chapter we have connected at least three policy arenas with a share in it: 1) the long-standing critique of progress to more sustainable development - including in urban contexts; 2) the limited results of the education agenda for sustainable development; and 3) the encouraging but still inadequate progress in the theory and practice of collaborative science and inter- and transdisciplinary processes. As the century advances from one crisis to another, affecting global ecology, financial and health systems, urban areas find themselves as key players in both causing the crises and potentially shaping transformative solutions. Cities are increasingly under pressure to respond and to imagine new sustainable pathways. For this, they need to enhance capacities for "participatory, integrated and sustainable" planning and management, as highlighted in Target 11.3 of the Sustainable Development Goals (UNGA, 2015), to be able to frame problems and solutions that have yet to be imagined.

In this chapter, we reflected on the interconnections between these three policy arenas through the lens of the inter- and transdisciplinary experiments at the local level, as presented in Parts II and III of this volume. We highlighted the strong link between the concept of learning and re-learning how to design and plan cities in a holistic manner, and collaborative and participatory processes entailing inter- and transdisciplinarity. We then argued for the need to further develop and integrate the necessary competences and dispositions into urban-related studies in higher education. The experience shows how, in addition to resistance and lack of capabilities and dispositions, scholars and practitioners are also confronted with contradictions between what is needed (and deemed ethical) and actual societal standards and expectations. The complex nexus between dispositions, risk-taking and courage is illustrative: on the one hand, risk-taking, for example, increases the likeliness of developing innovative solutions; on the other hand, it also increases the "risk" of failing (problems with funding institutions, publications, learning targets, etc.), which can rarely, if ever, be a valuable approach for practice. Yet, failures can be extremely productive and are seen as important for learning especially in design and planning processes (Sawyer, 2018).

To address the combination of resistance, limited capabilities and inevitable contradictions, our inter- and transdisciplinary experiments - the framework as well as the INTREPID journey - call for new educational models and a reprioritising of the kind of knowledge that needs to be taught, away from technical skills towards softer competences and dispositions. In our 16 accounts of inter- and transdisciplinary processes, we sought to strike a balance between enthusiastic support for their transformational potential and a cautious note regarding the persistent challenges to the ethos as well as the practice of inter- and trans-disciplinarity and cooperation. In this spirit, we have translated the lessons learned, and those still to be learned, into a framework that is simple, though by no means easy to apply when confronted with the persistent challenges of real-world inter- and transdisciplinarity (see Chapter I. 2 in this volume). Knowing what phases are critical in any collaborative and participatory process and making an early effort to allocate human and financial resources as well as time to each phase, will make a world of difference. Finally, learning, and the disposition to learn, may feel like an unsatisfactory conclusion for a journey into the joys and travails of actual inter- and transdisciplinary processes, and yet the experience we have shared within INTREPID's network is that trust, humility, and mutual and transformative learning are the too-often invisible levers of change, contributing to enable sustainable cities.

\section{Notes}

1 This is highlighted in Target 11.3 of the Sustainable Development Goals (UNGA, 2015).

2 For our definitions and more detail please see Part I, Chapter 2 in this volume.

3 Sustainable Development Goal no. 1 is "End poverty in all its forms everywhere" and Target 1.3 states that "By 2030, ensure that all men and women, in particular the poor and the vulnerable, have equal rights to 
economic resources, as well as access to basic services, ownership and control over land and other forms of property, inheritance, natural resources, appropriate new technology and financial services, including microfinance" (UNGA, 2015).

4 Moreover, as many have argued, Sustainable Development Goals can only be implemented if synergies and trade-offs are fully addressed (Sachs et al., 2019), and we note that Sustainable Development Goal no. 11's targets can entail considerable interdependence with at least 11 other goals: on Poverty (no. 1), Food (no. 2), Health (no. 3), Education (no. 4), Gender (no. 5), Water and Sanitation (no. 6), Energy (no. 7), Growth and Employment (no. 8), Infrastructure (no. 9), Inequality (no. 10) and Climate Change (no. 13).

\section{References}

Bina, O., Balula, L., Varanda, M., \& Fokdal, J. (2016). Urban studies and the challenge of embedding sustainability: A review of international master programmes. Journal of Cleaner Production, 137(20), 330-346. Doi: 10.1016/j.jclepro.2016.07.034.

Bina, O., Varanda, M., \& Guevara, M. (2019). INTREPID Knowledge: Interdisciplinary and transdisciplinary research and collaboration. Ersilia Foundation. http://intrepid-cost.ics.ulisboa.pt/wp-content/uploads/2019/09/INTREPID_ebook.pdf.

Brand, U. (2014). Social-ecological transformation as basic condition for a realistic post-2015 agenda. In: ÖFSE (Ed.), Die Post-2015 Agenda. Reform oder Transformation, pp. 49-54. Vienna: Österreichische Entwicklungspolitik, Analysen.

Brenner, N., Marcuse, P., \& Mayer, M. (Eds.) (2012). Cities for People, Not for Profit. New York: Routledge

Cirolia, L., Smith, W., \& Duminy, J. (2015). Grappling with housing issues at the city scale: Mobilizing the right to the city in South Africa. In: Herrle, P., Ley, A., \& Fokdal, J. (Eds.). From Local Action to Global Networks: Housing the urban poor. Ashgate.

Farha, L., \& Porter, B. (2017). SDG 1: Commodification over community: financialization of the housing sector and its threat to SDG 11 and the right to housing in UN Human Rights Council. In: Report of the Special Rapporteur on Adequate Housing to the Human Rights Council, pp. 105-110. Retrieved from https:// www.2030spotlight.org/sites/default/files/download/Spotlight2017_2_11_Farha_Porter.pdf (Accessed 18 March 2020).

Garschagen, M., \& Porter, L. (2017). The New Urban Agenda: From vision to policy and action. Planning Theory and Practice, 19(1), 117-137.

Göpel, M. (2016). The Great Mindshift: How a new economic paradigm and sustainability transformations go hand in hand. Springer International.

Griffith, C., Maddox, D., Simon, D., Watkins, M., Frantzeskaki, N., Romero-Lankao. P., et al. (Eds.). (2018). Urban Planet: Knowledge towards sustainable cities. Cambridge: Cambridge University Press.

Guimarães, M.H., Pohl, C., Bina, O., \& Varanda, M. (2019). Who is doing inter- and transdisciplinary research, and why? An empirical study of motivations, attitudes, skills, and behaviours. Futures, 112, 1-15. doi: https://doi.org/10.1016/j.futures.2019.102441

Harvey, D (2012). Rebel Cities, from the Right to the City to the Urban Revolution, Verso.

Hirsch Hadorn, G. Hoffmann-Riem, H. Biber-Klemm, S., Grossenbacher-Mansuy, S., Joye, D., Pohl, C., Wiesmann, U., and Zemp, E. (2008). Handbook of Transdisciplinary Research. Berlin: Springer.

Huchzemeyer, M. (2018). The legal meaning of Lefebvre's the right to the city: Addressing the gap between global campaign and scholarly debate. GeoJournal, 83, 631-644.

Hulme, M. (2009). Why We Disagree about Climate Change: Understanding controversy, inaction and opportunity. Cambridge: Cambridge University Press.

Jacobs, J. (1961). The Death and Life of Great American Cities. Random House, New York.

Jordan, T., Andersson, P. \& Ringnér, H. (2013). The Spectrum of Responses to Complex Societal, Issues: Reflections on Seven Years of Empirical Inquiry. Integral Review, 9(1), 34-70.

Kaika, M. (2017). "Don’t call me resilient again!”: The New Urban Agenda as immunology ... or ... what happens when communities refuse to be vaccinated with "smart cities" and indicators. Environment and Urbanization, 29(1), 89-102. doi:10.1177/0956247816684763

Klein, J.T. (2013). The Transdisciplinary Moment(um). Integral Review, 9(2), 189-199.

Lefebvre, H. (1968). Le Droit À La Ville. 2nd edn. Paris: Anthropos. 
Leicht, A., Heiss, J., \& Byun, W.J. (Eds.) (2018). Issues and Trends in Education for Sustainable Development. Paris: United Nations Educational, Scientific and Cultural Organization. Retrieved from http://creativecommons.org/licenses/by-sa/3.0/igo/.

Mayer, M. (2012). The "Right to the City" in Urban Social Movements. In: Brenner, N., Marcuse, P., \& Mayer, M. (Eds.), Cities for People, Not for Profit: Critical urban theory and the right to the city, pp. 63-85. London: Routledge.

Mitchell, C., Cordell, D., \& Fam, D. (2015). Beginning at the end: The outcome spaces framework to guide purposive transdisciplinary research. Futures, 65, 86-96.

Parnell, S. (2015). Defining a global urban development agenda. World Development, 78, 529-540.

Regeer, B. J. and Bunders, J. F. G. (2009). Knowledge co-creation: Interaction between science and society A transdisciplinary approach to complex societal issues, Study number V.10e, VU University Amsterdam Athena Institute.

Rieckmann, M. (2018). Learning to transform the world: Key competencies in Education for Sustainable Development. In: Leicht, A., Heiss, J., \& Byun, W.J. (Eds.). Issues and Trends in Education for Sustainable Development, pp. 39-60. Paris: United Nations Educational, Scientific and Cultural Organization. Retrieved from http://creativecommons.org/licenses/by-sa/3.0/igo/.

Sachs, J.D., Schmidt-Traub, G., Mazzucato, M., Messner, D., Nakicenovic, N. \& Rockström, J. (2019). Six transformations to achieve the Sustainable Development Goals. Nature Sustainability. doi: 10.1038/s41893019-0352-9

Satterthwaite, D. (2017). Will the New Urban Agenda have any positive influence on governments and international agencies? Planning Theory and Practice, 19(1), 117-137.

Sawyer, R.K. (2018). The role of failure in learning how to create in art and design. Thinking Skills and Creativity. https://doi.org/10.1016/j.tsc.2018.08.002 (accessed March 2020).

Schmid, C. (2012). Henri Lefebvre, the Right to the City, and the new metropolitan mainstream. In: Brenner, N., Marcuse, P., \& Mayer, M. (Eds.), Cities for People, Not for Profit: Critical urban theory and the right to the city, pp. 42-62. London: Routledge.

Schön, D. (1983). The Reflective Practitioner: How professionals think in action. Basic Books.

SDSN. (2016). Getting started with the SDGs in cities. Retrieved from http://unsdsn.org/resources/publications/ getting-started-with-the-sdgs-in-cities/ (accessed: 2 August 2016).

SDSN Australia/Pacific. (2017). Getting started with the SDGs in universities: A guide for universities, higher education institutions, and the academic sector. Melbourne: Sustainable Development Solutions Network (SDSN) - Australia/Pacific, Australia, New Zealand and Pacific Edition. Retrieved from http://ap-unsdsn. org/regional-initiatives/universities-sdgs/university-sdg-guide/ (accessed: 22 September 2017).

Sennett, R., Burdett, R., Sassen, S., \& Clos, J. (2018). The Quito Papers and the New Urban Agenda. New York: UN-Habitat.

Simon, D., Palmer, H., \& Riise, J. (Eds.). (2020). Comparative Urban Research from Theory To Practice: Coproduction for sustainability. Bristol: Policy Press.

UNCED. (1992). The Rio Declaration on Environment and Development. New York: United Nations General Assembly. Retrieved from http://www.unep.org/Documents.Multilingual/Default.asp?DocumentID=78 \&ArticleID=1163 (12/2/08).

UNESCO. (2017). Education for Sustainable Development Goals: Learning objectives. Paris: United Nations Educational, Scientific and Cultural Organization (UNESCO) Retrieved from http://unesdoc.unesco.org/ images/0024/002474/247444e.pdf (accessed: 22 May 2017).

UNGA. (2015). Transforming our World: The 2030 agenda for sustainable development. Geneva: UN General Assembly. Resolution adopted by the General Assembly on 25 September 2015.

UN-Habitat. (2009). Planning Sustainable Cities: Global report on human settlements. London: Earthscan.

Watson, V. (2016). Locating planning in the New Urban Agenda of the urban sustainable development goal. Planning Theory, 15(4), 435-448.

WBGU. (2017). New Urban Agenda: Implementation demands concerted effort now. German Advisory Council on Global Change (WBGU). Retrieved from http://www.wbgu.de/fileadmin/user_upload/wbgu.de/templates/dateien/veroeffentlichungen/weitere/WBGU-Stellungnahme_NUA_EN.pdf (accessed: 3 March 2017). 